E

51

N42Z

NMAI REF

no
CONIRIBUTIONS FROM THE HEYE MUSEUM

NUMBER 3

\title{
CERTAIN KITCHEN - MIDDENS IN
}

\author{
J A M A I C
}

IBY THEODOOR DE BOOY

PROPERTY OF GEORGE G. HEYE 


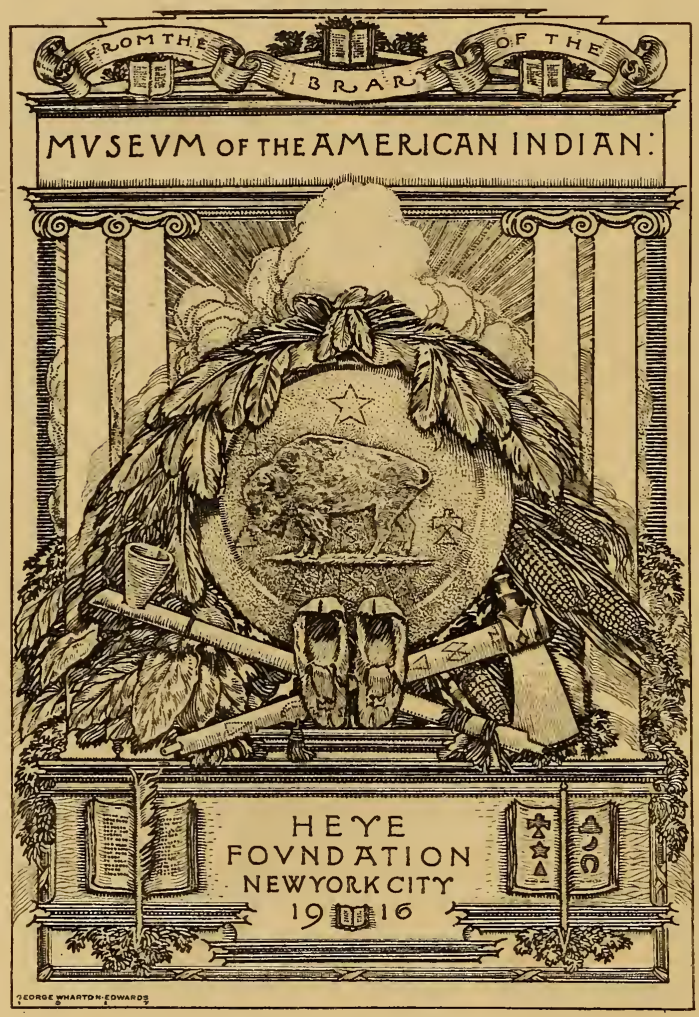


Peorge A. Heye. Peqke with the reateful compliments of
the author

$$
c \text { Jheodors depooy. }
$$



1075 

CONTRIBUTIONS FROM THE HEYE MUSEUM

NUMBER 3

\section{CERTAIN KITCHEN-MIDDENS IN \\ JAMAICA}

By THEODOOR DE BOOY

Reprinted from the AMERICAN ANTHropologist (N.S.), Vol. XV, No. 3, July-September, I9I3

Lancaster Pa., U. S. A. The New Era Printing Company 1913

JUL 202000 U 



\section{CERTAIN KITCHEN-MIDDENS IN JAMAICA}

\section{By THEODOOR DE BOOY}

D

URING a sojourn on the island of Jamaica in the months of January, February, and March, I9I3, in the interest of the Heye Museum of New York City, the author was enabled to excavate some of the typical aboriginal kitchen-middens found in various parts of the island. These middens shed much light on the mode of life of the pre-Columbian inhabitants, and, above all, allow a practically exact determination of their different foodstuffs. At the same time, such ceramic fragments and other artifacts as one can find-and they occur in great quantitiesare most valuable for comparative studies of the prehistoric cultures that existed in the West Indies.

The modern equivalent of the kitchen-midden is the ash-heap: where, nowadays, we cast our broken kitchen utensils, bottles, and empty cans, the natives threw their broken pots and cookingslabs, their shells, and such stone artifacts as happened to break in the making or during use. It can therefore readily be seen what important conclusions can be drawn from the varied specimens found in a midden. The author considered himself especially fortunate in being able thoroughly to examine and excavate a number of these refuse heaps.

The writer wishes to express his sincere thanks in behalf of the Heye Museum and himself to the Reverend J. P. Hall, of Brown's Town, Jamaica, for facilities given him in this work, for generous permission to excavate, and for the material from the middens and from other sources presented to the Heye Museum.

In Dr J. F. Duerden's work on the archeology of Jamaica ${ }^{1}$ the following paragraph can be found on page I9:

${ }^{1}$ Aboriginal Indian Remains in Jamaica, Journal of the Institute of Jamaica, vol. II, no. 4, Kingston, 1897 .

AM. ANTH., N. S., $x_{5}-29$ 
RETREAT.-These deposits are on the property Retreat, situated between Brown's Town and Stewart Town, in St Ann, about four miles from the former. The land is now owned by Mr Roper, but was formerly in the possession of $\mathrm{Mr}$ Moulton Barrett. Miss Moulton Barrett made a number of investigations at the place and lent to the Anthropological Exhibition a collection of pottery fragments obtained. . . . The hill or ridge upon which the kitchen-middens are found is about $\mathrm{I}, 200$ feet high, and six miles from the sea. . . . The elevation in question was very significantly known by the former owners as "Cacique's Ridge," and is also known as Little Nigger-ground Hill, while a higher one near has the title of Big Nigger-ground Hill. These latter names recall the fact that in slavery days the particular spots were used by the Negroes as provision grounds. . . . Excavations were made at numerous spots, and, in all, scattered amongst the upper dark loose earth and fragments of limestone, were broken pieces of pottery, quantities of land shells, a few specimens of marine shells, and the bones of the Indian coney and of various fish. This foreign material extended in several places to a depth of two feet. In one a deposit of partially indurated bluish-gray ash and charcoal gave evidence of the use of fire by the builders of the refuseheaps.

At the time of the author's excavations the Retreat property was owned by Mr Hall, and since the investigations of Dr Duerden in I 896 no excarations had been conducted on Little Nigger-ground hill. Figure II I shows the top of the hill. The actual crest of the hill is almost level, and the middens can be readily seen on the northern, eastern, and southern slopes, around the crest. The author determined sixteen middens with accuracy by digging small test-holes in the soil wherever there was a hummock. There may be sereral more middens on the hill, which in the course of time have altered in shape or the original summit of which has been remored by the excarations of Dr Duerden and previously by those of Miss Moulton Barrett.

The western part of the top of Little Nigger-ground hill is a rocky woodland. There was no proof that it had been used as part of the rillage site, nor could eridence of burials be discorered.

Little Nigger-ground hill (fig. II2) is situated about six miles from the sea. It does not afford a view of the sea, as it rises between the surrounding hills; but sentinels could readily perceive the approach of marauding Caribs and give ample warning to enable escape to the neighboring hills in the interior in case of a raid. An old road, in reality little more than a footpath, still extends from the hill to the sea, and is reported to have been made by the Spaniards. It is quite within the bounds of probability that 
this road was an aboriginal path, and that the Spaniards afterward used and enlarged it for their own purposes. The plain due north of Little Nigger-ground hill is fertile and suggests an ideal place for the cultivation of cassava.

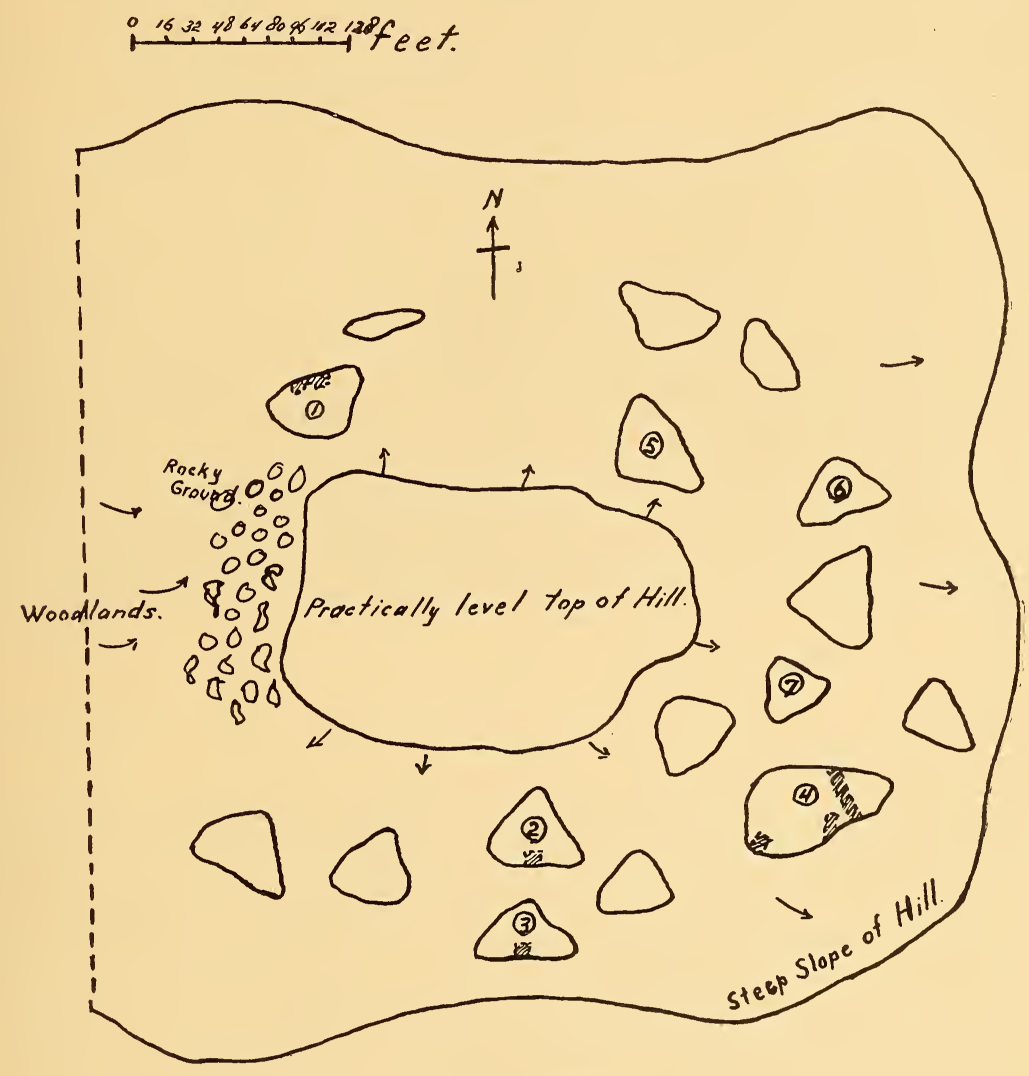

FIG. II I.- " Retreat" village and middens.

\section{Excavations in the Middens}

Excavations were commenced in the midden marked $\mathrm{I}$ in figures I I I and II3. This midden is on the northern slope of the hill, and, as can be seen on the plan, is somewhat isolated from the other middens, there being a very small midden in front of it, but otherwise no other mounds within 160 feet. Midden I is 42 feet long and 30 feet wide; the crest has a height of 4 feet above the slope. 
Excavation in this midden produced the same kind of material as afterward was found in midden 4, of which a detailed account follows. As three trenches were dug in midden 4 and only one in

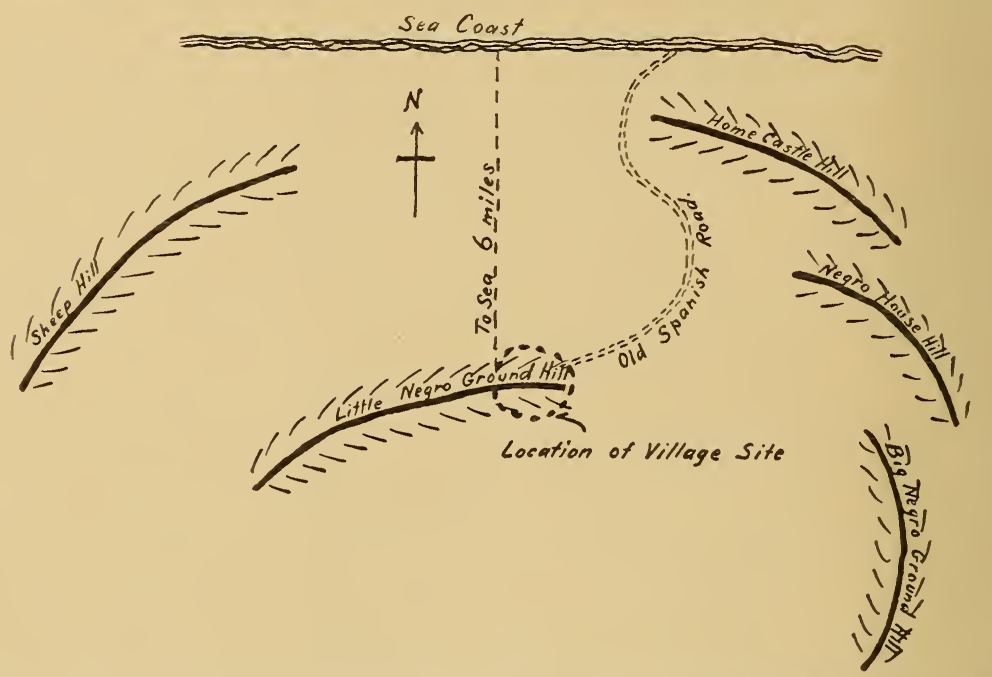

FIG. I I2.- “Little Negro Ground" hill, with neighboring hills. (Not to scale.) the first midden, it is preferable to give the detailed account of the excavations in the larger refuse heap. It is, however, of interest to note that such pottery fragments as were found in midden I were

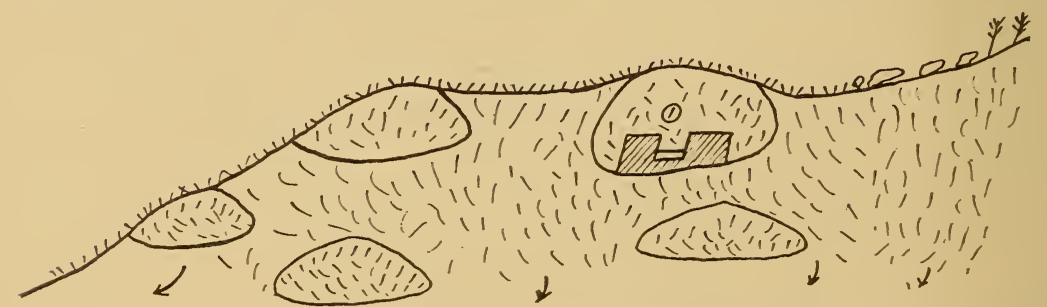

FIG. II3.-Side elevation of "Retreat" village site, looking south, showing middens on slope. (Not to scale.)

far more brittle and were smaller than those from the other accumulations. This was due probably to the better drainage of the southern slope of the hill.

Midden 2 is on the southern slope of the hill and did not produce much material. This midden has a more pointed crest than any of 

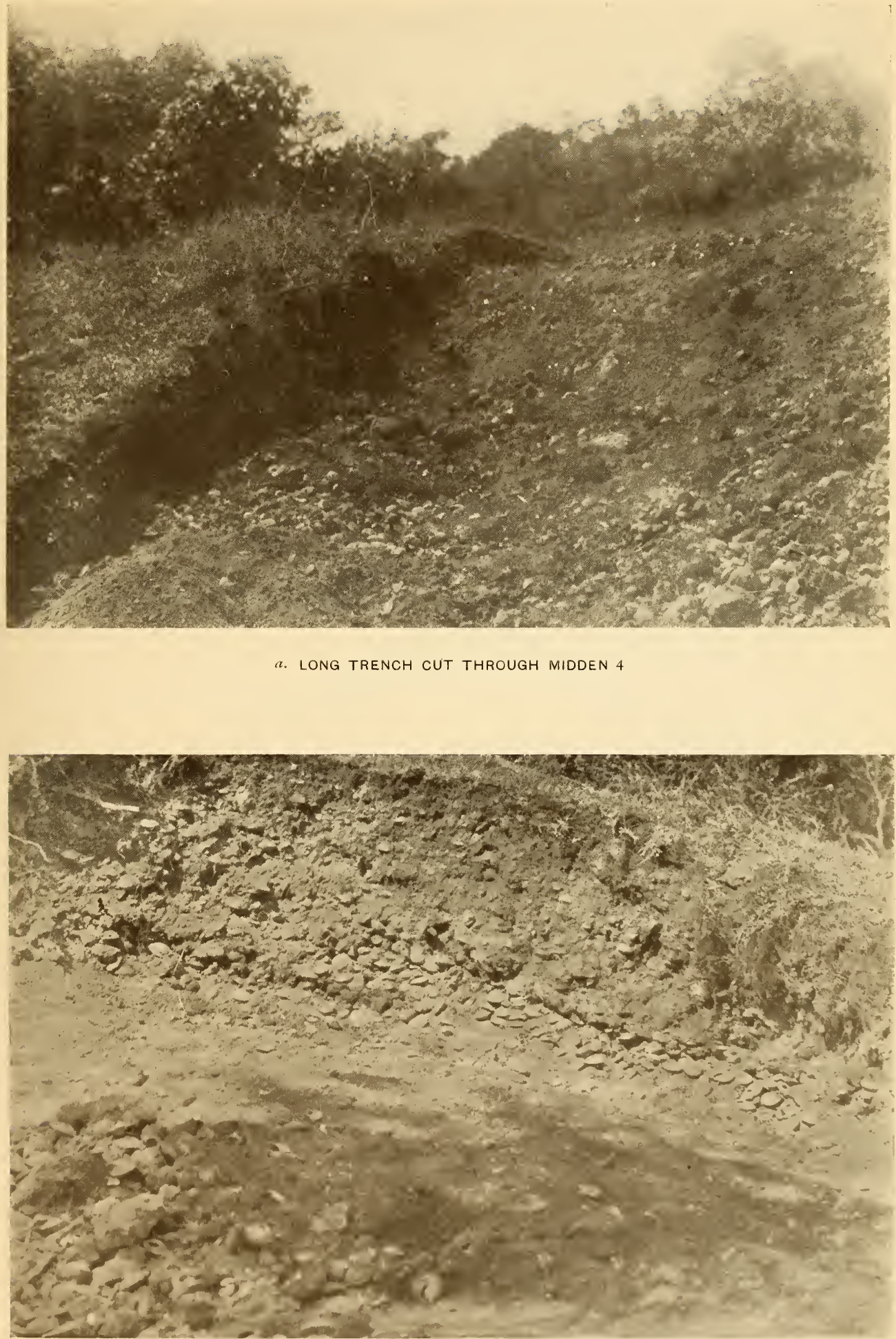

the others and could not have afforded space for more than a single hut.

Midden 3 is directly south of midden 2, but about twenty feet lower down on the slope of the hill. This midden also was not very productive, but, on the other hand, the sherds were in far better condition than those from the other site.s.

It was in midden 4 (figs. I I I, I I4, I I5) that the most extensive excavations were made. The latter part of these excavations was not made with the purpose of obtaining more archeological material, but with the idea of procuring as accurate information as possible regarding the location of the huts and the exact limits of the shell and ash deposits.

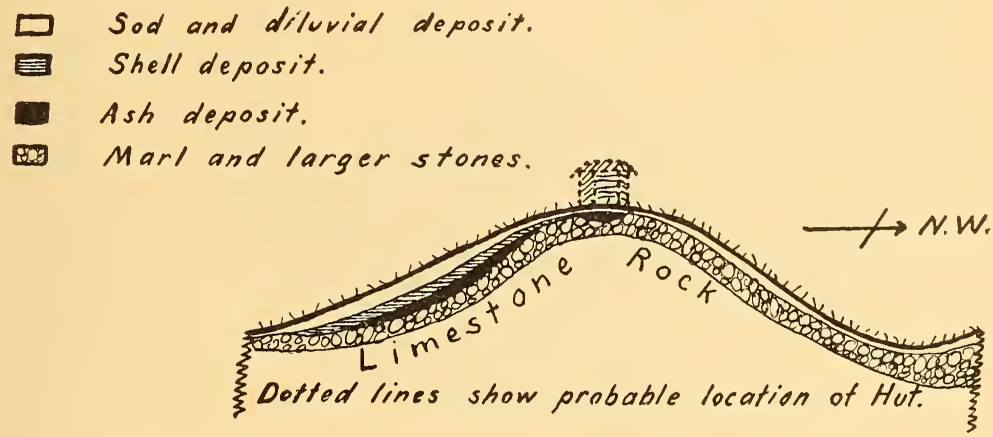

FIG. II 4.-Cross-section of midden 4. (Not to scale.)

As in all previous excavations on Little Nigger-ground hill, an enormous number of land-snail shells were unearthed; indeed, from test-holes dug in midden 4 , the author computes that this midden alone contained more than 300 cubic feet of shells.

Three trenches were dug in this midden, besides a large number of test-holes. The first trench (A, fig. I I 5) was i 4 feet long by io feet wide, with varying depth down to marl. This trench extended in a south to north direction. At the most northerly point the marl came immediately under the diluvial deposit and the sod, and no shells, ashes, or artifacts were found. The second trench (B) was 38 feet long by ro feet wide and followed a southeast-northwest direction, with a depth of four feet at the southeastern end, down 
to marl, and a depth of less than a foot on the crest. This trench was purposely continued beyond the crest, with a view of verifying the test-holes previously dug. As will be shown later, this long trench gave important testimony as a basis for a hypothesis concerning the exact location of the aboriginal abode. The third trench (C, fig. II 5) was Io feet long and Io feet wide.

At the point marked $\mathrm{B}$, the author started the second trench by having the sod and diluvial deposit remored. This was a foot thick at the base of the midden, where the trench was begun. Proceeding toward the crest, after a distance of a foot, a layer of shells was found under the diluvial deposit, which layer gradually

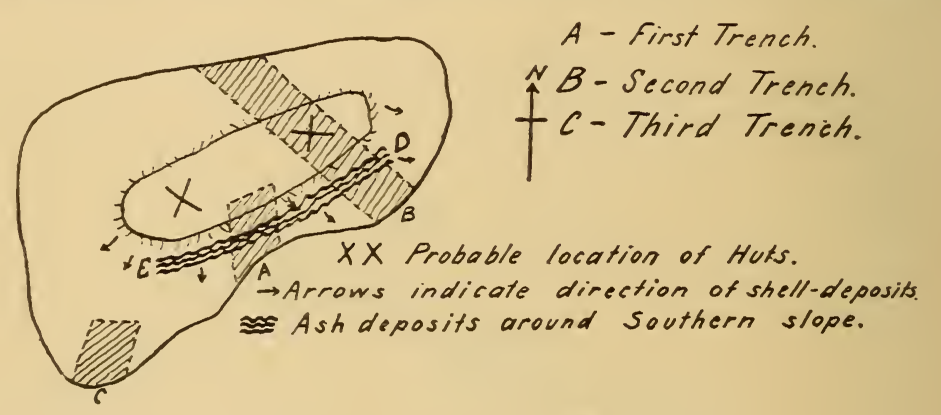

FIG. II5.-Top view of midden 4. (Not to scale.)

increased from a thickness of six inches at the very base to a thickness of a foot about two feet inward, and then tapered gradually to a single shell or two at the summit of the mound. Following the trench down the opposite slope, no shells were found. Mingled with the shells on the southern slope of the midden were the artifacts, such as worked stones and pottery fragments, many of the latter in excellent condition. The ash deposit commenced four feet above the foot of the slope and continued to the summit. This deposit was from 8 to 12 inches in thickness, and in it were found sherds, bones, worked stones, etc. No ashes were found on the northern slope of the midden. Test-holes showed that the ash deposit extended round the southern slope, covering in all about half the circumference of the midden, while the shell deposit covered about 270 degrees of the circumference. On the crest of the midden 

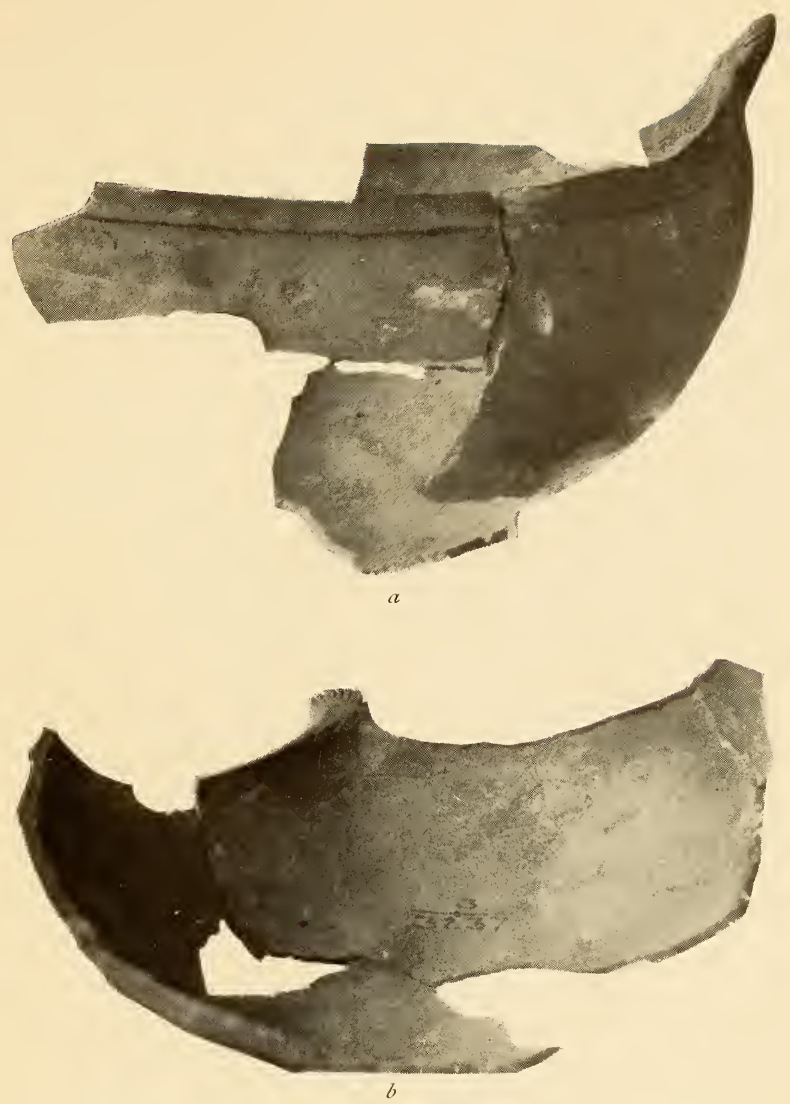

$a, b$. FRAGMENT OF BOAT-SHAPED VESSEL. (THREE-FOURTHS)

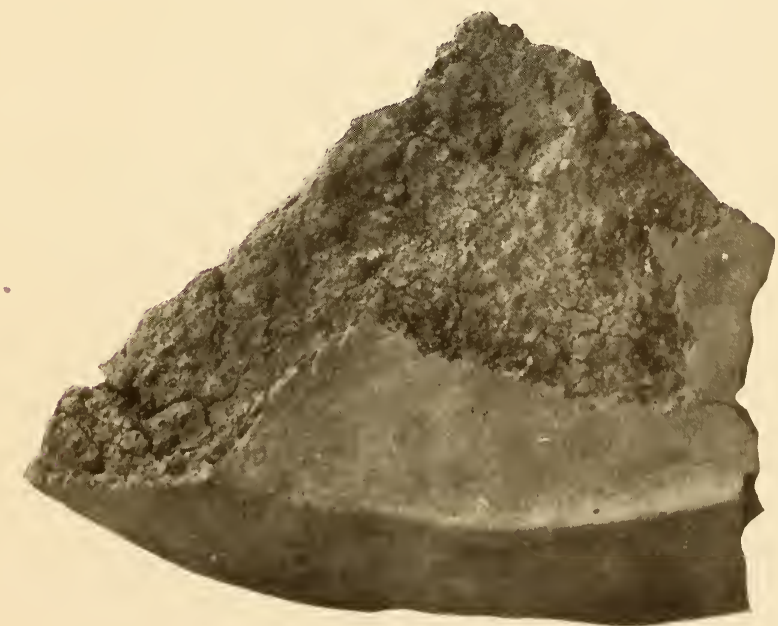

FRAGMENT OF CLAY GRIDDLE. (ONE-HALF) 

two ash-pockets were found, about two feet in diameter and I2 inches deep, surrounded by stones about the size of a man's head. The presence of these ash-pockets is problematical, as the aborigines certainly did not need a fire to keep their abode warm in a tropical climate, and the semicircle E-D (fig. II5) around the hummock supports the theory that cooking was done on the slope of the midden rather than on the crest. It is not from the two ashpockets, but from the direction of the shell and ash deposits, that the author reaches the conclusion that the aboriginal abode was situated on top of the hummock and has formed the theory that the inhabitants threw the refuse and the discarded artifacts in three quadrants of the circle: in other words, in all directions save one, which afforded them at least one clean, clear space in front of the hut.

That the native made use of a natural rise of the ground on which to build his hut can plainly be seen in plate XxxI, $a$, which illustrates the long trench (B) cut through midden 4 . It can here be seen that the contour of the midden is practically the same as that of the surface of the ground, as the trench was cut down to marl and all loose earth, shells, and ashes had been taken out before the photograph was made.

A good idea of the shell deposits can be had from figure $b$ of the same plate, in which a section of trench $\mathrm{A}$ in midden 4 is shown. In all the middens on Little Nigger-ground hill at least 98 per cent. of the shells found were those of land-snails, the remainder being seashells. The author gathered specimens of the different species and a later examination identified them as follows:

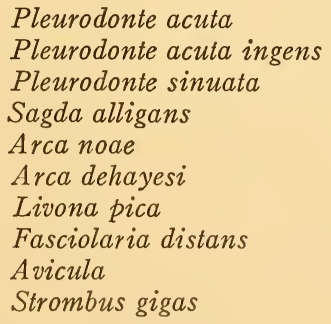

Various small animal bones were found in the middens, but the 
identification of these has not been possible. It is certain, however, that some of them belonged to the utia (Capromys). There also were many fish-bones, and these for the greater part have been identified as belonging to the rock-fish (Mycteroperca), which at the present time is regarded as one of the most edible fishes in the Caribbean.

\section{Archeological Specimens from the Middens}

The predominating type of pottery vessel in these middens, as well as in other middens of Jamaica investigated by the author, is a boat-shaped type, and while naturally no entire vessel was found, enough remains of several of them to show their form quite distinctly. In plate XXXII, $a, b$, is shown part of a vessel of this type, made of a dark-red clay, partly blackened either in the firing or by usage. The wall of the vessel is not more than one-eighth of an inch thick, and with the exception of the handle, which shows a few simple incised lines, it is undecorated. The rim is incurving and has a banded edge.

Many of these boat-shaped vessels have handles that are more elaborately decorated, and one occasionally finds handles that show a conventionally modeled parrot's head. Human heads also are depicted. Plate xxxiII, I, shows some of the handles of these types. Fragments of decorated rims also were found in abundance, the decoration consisting chiefly of straight-line incisions, while serrated lugs under the rim are not uncommon.

The difference between Jamaican pottery and that from the neighboring islands impressed the author as being quite considerable; this is especially noticeable in the type of handles and in the fact that in the rectilinear decorations on sherds from most of the other islands an indentation made with the same tool that made the incised lines is found, which does not occur on any of the many hundreds of sherds collected by the author in Jamaica. This feature is described by Dr J. Walter Fewkes ${ }^{1}$ as follows:

A marked feature in rectilinear decoration is the indentation of the extremity of each line. The potter commonly terminated a line with a shallow pit that was

\footnotetext{
${ }_{1}^{1}$ The Aborigines of Porto-Rico, Twenty-fifth Annual Report, Bureau of American Ethnology, Washington, I907, p. I80.
} 


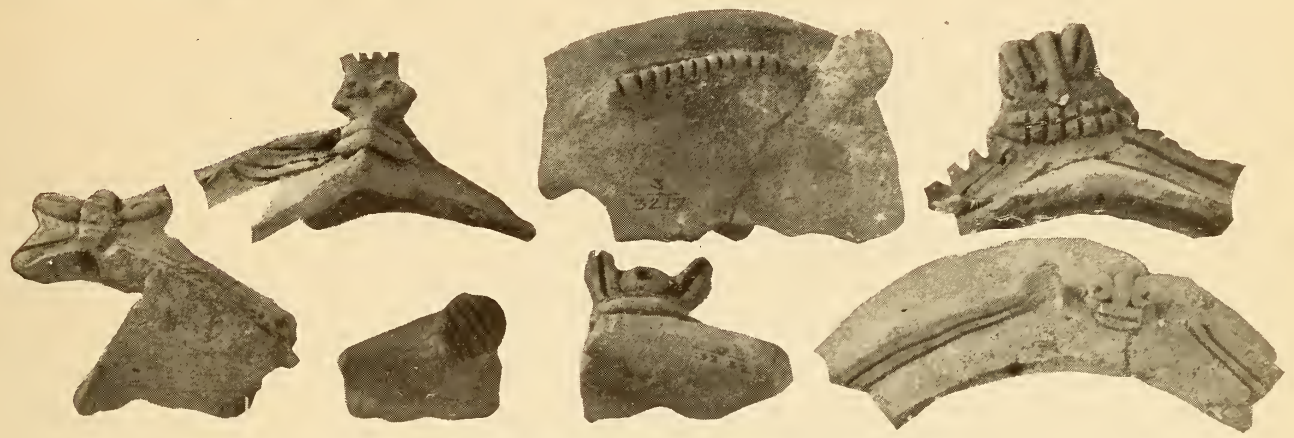

1. HANDLES OF VARIOUS TYPES. (TWO-THIRDS)

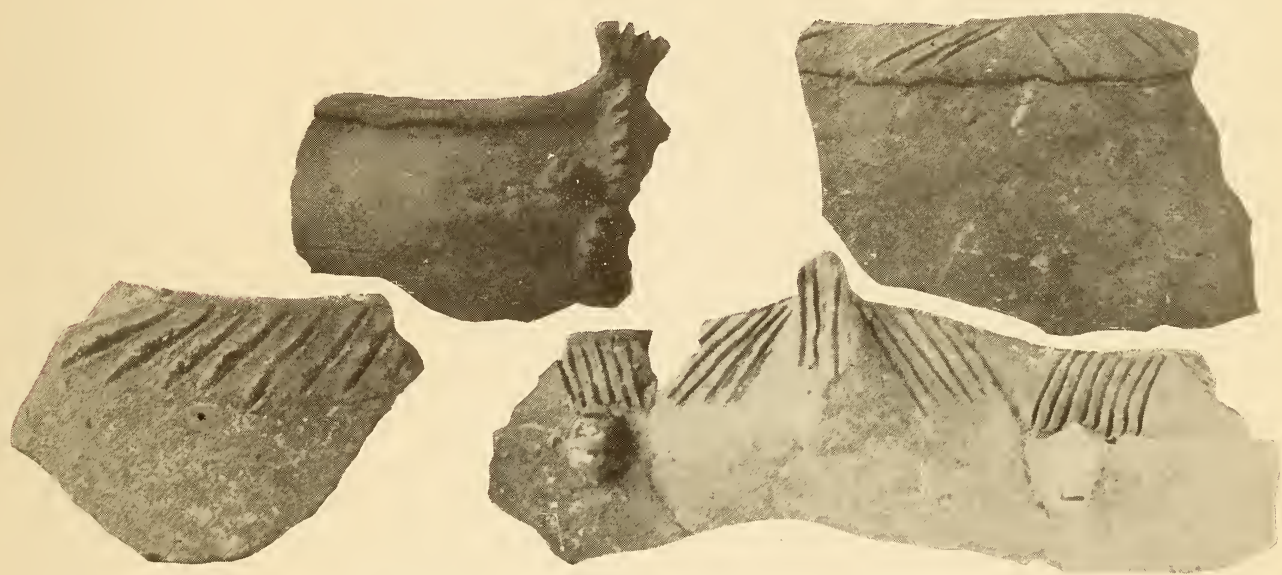

2. SHERDS WITH INCISED DECORATION. (ONE-HALF)

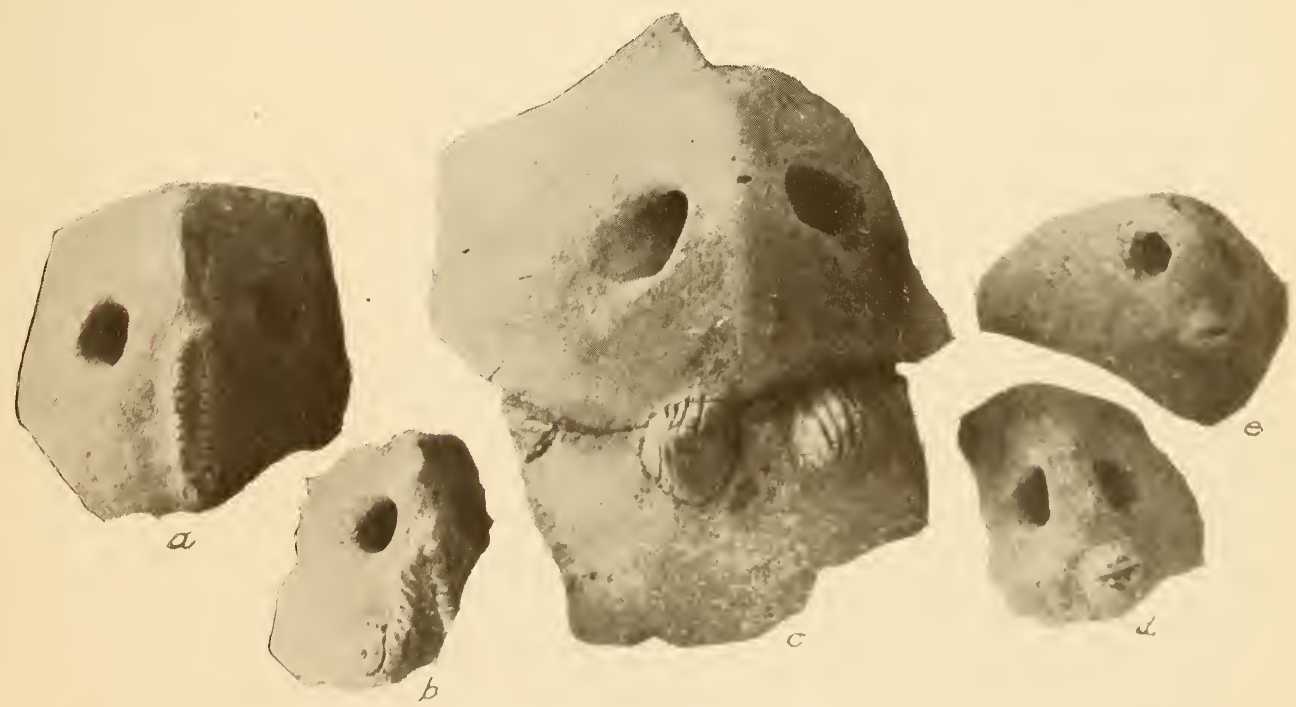

3. TYPICAL JAMAiCAN handLEs. (TWO-THIRDS) 

apparently made with the same instrument as the line itself: or it was sometimes slightly separated from the end of the line. So constant, almost universal, is this feature that it may be looked on as characteristic of pottery from Porto Rico and Santo Domingo.

This feature was also noted by the author in the sherds found on the Caicos islands and the Bahamas, which, on comparison, can hardly be distinguished from Santo Domingo sherds. Dr Fewkes also says (page I88) in the work referred to:

Illustrations $b, c$, and $d$ are representations of fragments of pottery from Nipe Bay, Cuba, and show the striking resemblance between the ceramics of Porto Rico and those of the largest of the Antilles.

It would therefore appear that the Jamaica pottery should not be included in the culture-type of that of Porto Rico, Hayti, Cuba, and the Bahamas, but that it belongs in a class by itself. It is rare to find impressed decorations on Jamaican pottery, and in the few instances in which it is found, the ornamentation is crude. On the other hand, as can be seen in plate xxxiII, 2 , some of the incised decorations are fairly elaborate.

The middens of Little Nigger-ground hill also produced a type of handle that is not found in the other West Indian islands. Dr Duerden figures one of this type in his monograph above referred to, and it seems to be found in middens in various parts of Jamaica, with only slight variations in size and decoration. Plate xxxıI, 3 , illustrates a few handles of this type. Whereas all the pottery previously described has a uniform thickness of from one-eighth to three-sixteenths of an inch, the thickness of the vessel to which this type of handle belongs is at least a quarter of an inch, and increases to not less than half an inch at the back of the perforation. Raised, serrated ornamentation is shown under the perforations in some cases (pl. xxxIII, $3, a$ ); in other specimens two small lugs were added by the potter $(c)$; again, a kind of scrollwork $(b)$ is employed, as if the potter endeavored in her crude way to represent the tentacles of an octopus; while in $d$ and $e$, two fragments belonging to the same vessel, an attempt may have been made to indicate a mouth, belonging to a face, of which the ridge between the perforations would represent the nose and the perforations the eyes. 
Besides earthenware ressels, the middens also produced many fragments of clay griddles (pl. xxxir, c). These are about an inch thick at the base and taper to a thickness of half an inch in the middle. They had a diameter of about I4 inches, but one finds only comparatively small fragments of these objects, which more than likely is due to the fact that the action of fire made them more brittle than the other ceramic objects.

The author found the usual worked stones in the middens, consisting of celts of the petaloid type, hammerstones, and rubbing and smoothing stones. A single specimen of shell celt was found, fashioned from the lip of a conch.

Heye MUSelM

New York CitY 







SMITHSONIAN INSTITUTION LIBRARIES

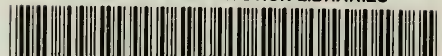

39088016099525 